\title{
"Everyone is becoming a forester": From state monopoly to participatory forest management in Sao Hill Forest, Tanzania, c.1990-2015
}

\author{
Hezron R. Kangalawe and Sandra Swart*
}

\begin{abstract}
In 2000, Sao Hill Forest, the biggest state-owned plantation in Tanzania, was forced to adopt "community forest management" - a paradigm usually adopted in protecting only natural forests. We hope to contribute to the scholarship on forest management by using this unusual case study - taken from plantation forests. Research on community or participatory forest management has focused on natural forests - but plantations offer different issues to consider. We argue that the state was compelled to adopt, but also adapt to the model of community management in order to fit a neoliberal donor context while, on a practical level, protecting it from local environmental hazards. To contextualise this historical case-study, we explain why Sao Hill stagnated and then examine the survival strategies adopted by the managers at the plantation. We then explore the relationship of the forest project with the surrounding communities, highlighting different local and vernacular responses to what came to be understood as "community forest management". We use this case study to examine this idiographic application of community resource management, in order to demonstrate the real-world use of environmental history in informing current policy decisions.
\end{abstract}

Keywords: Tanzania; Sao Hill Forest; World Bank; plantation forests; participatory forest management; community-based resource management; environmental history; forest history.

\footnotetext{
* Hezron Romanus Kangalawe is a lecturer in the Department of History, University of Dar es Salaam, Tanzania and an associate of the Department of History, Stellenbosch University, South Africa. Email: kangalawe1982@gmail.com. Sandra Swart is a professor in the History Department, Stellenbosch University, with a DPhil in Modern History and an MSc Environmental Change and Management, both from Oxford University. She focuses on southern African socio-environmental histories, especially the shifting relationships between humans and animals. Email: $\underline{\text { SSS@sun.ac.za }}$
}

\footnotetext{
How to cite this article: H.R. Kangalawe and S. Swart, “'Everyone is becoming a forester': From state monopoly to participatory forest management in Sao Hill Forest, Tanzania, c. 1990-2015”, Historia, 66, 2, November 2021, pp 74-100. 


\section{Opsomming}

In 2000 moes Sao Hill Forest, die grootste staatsplantasie in Tanzanië, noodgedwonge 'n stelsel van gemeenskapsbestuur aanvaar - 'n benadering wat gewoonlik slegs vir die beskerming van natuurlike woude gebruik word. Ons hoop om met behulp van hierdie ongewone gevallestudie van 'n bosbouplantasie 'n bydrae te lewer tot die studie van die bestuur van woude. Navorsing oor gemeenskaps- of deelnemende bestuur van woude fokus hoofsaaklik op natuurlike woude. Bosbouplantasies het egter ander kwessies/uitdagings om te oorweeg. Ons argumenteer dat die staat verplig was om die model van gemeenskapsbestuur te aanvaar, maar ook aan te pas ten einde by 'n neoliberale skenkerskonteks te pas, terwyl hulle hul op 'n praktiese vlak terselfdertyd teen plaaslike omgewingsgevare moes beskerm. Ten einde hierdie historiese gevallestudie te kontekstualiseer, verduidelik ons waarom Sao Hill gestagneer het en ondersoek dan die oorlewingstrategieë wat deur die bestuurders op die plantasie geïmplementeer is. Vervolgens ondersoek ons die verhouding van die bosbouprojek met die omliggende gemeenskappe, en beklemtoon verskillende plaaslike en inheemse reaksies wat as `n stelsel van gemeenskapsbestuur bekend geword en verstaan is. Ons gebruik die gevallestudie om hierdie idiografiese toepassing van gemeenskapshulpbronbestuur te ondersoek en te illustreer hoe omgewingsgeskiedenis in die praktyk aangewend kan word om ingeligte beleidsbesluite vir die hede te neem.

Sleutelwoorde: Tanzanië; Sao Hill Forest; Wêreld Bank; bosbouplantasies; deelnemende bestuur van woude; gemeenskaps-bestuur van woude; omgewingsgeskiedenis; bosgeskiedenis.

\section{Introduction}

Participatory forest management has attracted a robust and largely favourable scholarship within forest sustainability studies because it is deemed to improve both forests and the livelihoods of the surrounding communities. ${ }^{1}$ The participatory or community management model has generated debate over its challenges, such as state or local corruption, or its viability for generating profit at village level. ${ }^{2}$ Communitybased Resource Management (CBRM) has paradigmatically challenged the "tragedy of the commons" narrative, propagated from 1968 by Garrett Hardin's contention that whenever people are allowed free access to a natural resource, they compete in plundering it or allow its degradation, until the resource is exhausted. This precipitated the Manichean polarities of total state control or absolute individualised privatisation. Since the 1980s, however, the inescapable tragedy narrative has been contested by

1. V.G. Vyamana "Participatory Forest Management in the Eastern Arc Mountains of Tanzania: Who Benefits? The International Forestry Review, 11, 2, 2009, pp 249-250.

2. D. Brockington, "Forests, Community Conservation, and Local Government Performance: The Village Forest Reserves of Tanzania", Society and Natural Resources, 20, 9, 2007, pp 839- 845; H. Vihemäki, "Politics of Participatory Forest Conservation: Cases from the East Usambara Mountains, Tanzania", The Journal of Transdisciplinary Environmental Studies, 4, 2, 2005. 
anthropologists, economists, political scientists and historians, who have demonstrated long-standing methods deployed by communities to use their natural resources sustainably. Elinor Ostrom and others put forward a very different model to Hardin, arguing that history demonstrates the avoidance of the "tragedy of the commons" over the longue durée. ${ }^{3}$ This led to the rise of participatory forestry management, which built Ostrom's community model into resource management.4 However, this has not proved a panacea for all problems facing the forest sector (as we shall show) but it has become the most significant approach on a practical and ethical level. 5

In this article, we analyse the specific form that "participatory forest management" took in the Tanzanian plantation forests. This has not been addressed previously by the key historians of forestry such as Thaddeus Sunseri ${ }^{6}$ and Brett Bennett. ${ }^{7}$ It is within this context of protecting forests and improving livelihoods of the surrounding communities that we explore a singular case study, which also showcases the practical use of environmental history in informing policy decisions. This study focuses on plantation forests, whereas conventionally research on community forest management has concentrated on natural forests - but, as we will show, plantations offer different issues to consider like local employment, impacting on the relationship between plantation managers and communities. ${ }^{8}$ We use the case of Sao Hill, which is the biggest plantation forest in Tanzania with 135903 hectares. It is in Mufindi district, in the Iringa Province, south-western Tanzania.

3. M.C. Lopez and E.F. Moran, "The Legacy of Elinor Ostrom and its Relevance to Issues of Forest Conservation", Current Opinion in Environmental Sustainability, 19, 2016, pp 4756.

4. C.C. Gibson, J.T. Williams and E. Ostrom, "Local Enforcement and Better Forests, World Development, 33, 2, 2005, pp 273-284.

5. T. Blomley and H. Ramadhani "Going to Scale with Participatory Forest Management: Early Lessons from Tanzania, The International Forestry Review, 8, 1, 2006, pp 95-98.

6. T. Sunseri, Wielding the Ax: State Forestry and Social Conflict in Tanzania, 1820-2000 (Ohio University Press, Ohio, 2009), pp 94-95.

7. B.M. Bennett, "Locality and Empire: Networks of Forestry in Australia, India and South Africa, 1843-1948”, PhD thesis, University of Texas, Austin, 2010, p 1.

8. Local communities are "communities of any size that are in or adjacent to a forest plantation, and also those close enough to have a significant impact on the economy or the environmental value of the forest plantation or to have their economies, rights or environments affected significantly by the management activities or the biophysical aspects of the plantation". See M.B. Degnet, E. van der Werf, V. Ingram, and J.H.H. Wesseler, "Do Locals Have a Say? Community Experiences of Participation in Governing Forest Plantations in Tanzania", Forests ,11, 7, 2020, p 782. 


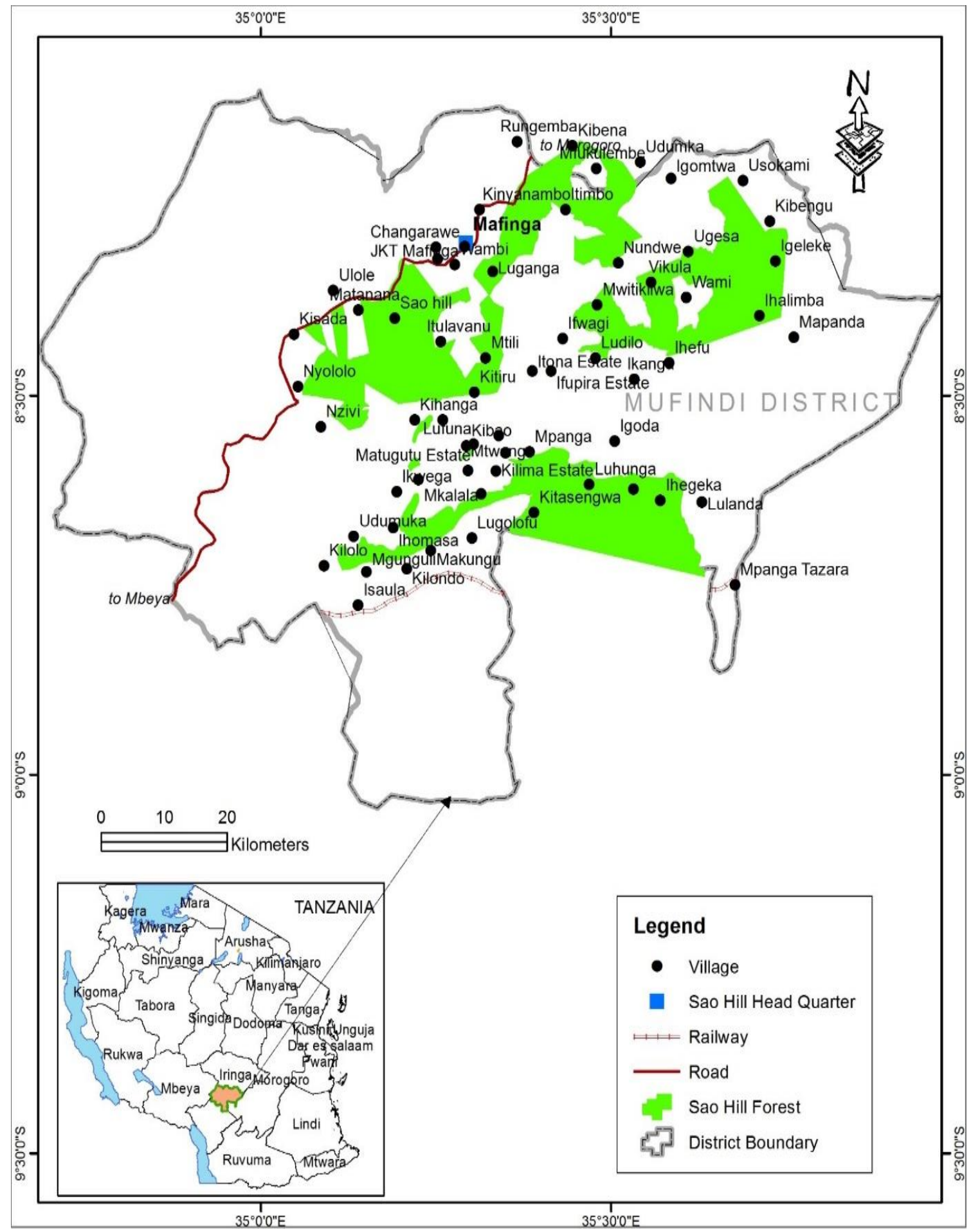

Figure 1: Map of Mufindi district showing the coverage of Sao Hill Forest with boundaries based on 1976 government gazettement. ${ }^{9}$

The forest began simply as an experiment by British colonial conservators in the late 1930s. Because of its size, it came to act as the key research centre for forestry in Tanzania. After independence in 1961, the post-colonial government viewed the forest as a key part of its industrialisation agenda and central to the development ambitions of the post-colonial economy. However, forest managers were sidelined in

9. Source: GIS (Geographical Information Systems), University of Dar es Salaam, June 2016. 
President Nyerere's blueprint for radical change. ${ }^{10}$ The following twenty years saw a top-down project of socialist development, with authorities being dominated by the ruling party. By the early 1980s, Tanzania experienced a financial crisis precipitated by economic bungling on the part of parastatal corporations and an expensive war with Uganda. So, the state agreed to a radical reverse in its ideological positioning to draw in foreign investment. This led to a shift from centralised planning to embracing market-based forces, privatising parastatals, and cutting back state-supplied social services. $^{11}$

Up until the 1970s, "industrial forestry" was managed by technocrats, with state and foreign donor support of parastatal sawmills. But the economic crisis compelled foresters to manage with reduced budgets and sawmills were divested and stripped of their subsidies. By the mid-1970s, they had already recognised forestry's financial challenges, which led to their request for a loan from the World Bank in 1976.12 The World Bank and the government of Tanzania

...both had a common interest in drawing - or forcing - subsistence producers into a greater production for and dependence on the market. ... [so] the alliance between a "capitalist" World Bank and a so-called "socialist" Tanzania ceases to surprise and begins to seem all but inevitable. ${ }^{13}$

Certainly, from the mid-1970s the World Bank inserted itself or was drawn into (depending on one's political view) almost all facets of Tanzania's agricultural production.

As will be explained, Tanzanian plantation forestry underwent a radical phase of economic liberalisation between 2001 and 2015 that saw the lifting of the government monopoly over some economic activities to admit the private sector. Economic liberalisation meant that new management regimes had to accommodate private forest developers. The coming of these independent forest developers posed a challenge to land ownership and indeed the general security of the state forests. To respond to these challenges, the Sao Hill Forest management forged a number of strategies. Earlier, in 1985, the Southern Paper Mills Company had started processing

10. A.W. Hurst, "State Forestry and Spatial Scale in the Development Discourses of PostColonial Tanzania, 1961-1971", The Geographical Journal, 2003, 169, 4, 2003, pp 358369; and E. Mgaya, "Forest and Forestry in Tanzania: Changes and Continuities in Policies and Practices from Colonial Times to the Present", Journal of the Geographical Association of Tanzania, 36, 2, 2016, pp 45-58.

11. For more detail see H. Campbell and Howard Stein (eds), The IMF and Tanzania: The Dynamics of Liberalisation (Southern Africa Political Economy Series Trust, Harare, 1991).

12. See H. Kangalawe, "Plantation Forestry in Tanzania: A History of Sao Hill Forests, 19392015”, PhD thesis, Stellenbosch University, 2018.

13. C. Payer, "Tanzania and the World Bank," Third World Quarterly, 5, 4, 1983, pp 791-813, especially p 797. 
wood from Sao Hill - then the largest industrial development project in Tanzania. ${ }^{14}$ By 1998, private investors (from within and outside the country) had become interested in profit-driven woodlot development. ${ }^{15}$ The Sao Hill plantation had been sustained previously for almost 14 years by World Bank loans between 1976 and 1990. ${ }^{16}$ From the late 1970s, donor-driven assessments showed that the state was failing to protect forest resources, which endangered not only ecological biodiversity, but the sustainable supply of wood products. ${ }^{17}$ A village afforestation crusade called Miti $n i$ Mali (Trees are Wealth) was implemented but made little impact. ${ }^{18}$ In 1990 the World Bank funding came to an end and its final report enumerated a number of doubts over the sustainability of the Sao Hill project, concluding that "the management of industrial plantations, such as Sao Hill, cannot be successfully carried out under normal government bureaucracy". ${ }^{19}$ In particular, the World Bank was sceptical of the byzantine bureaucracy that had developed during the previous 14 years of assistance. A radical change was necessary.

We use the Sao Hill plantation forest as a case study because this is the largest plantation forest in Tanzania and, indeed, the biggest in the (then) British East African colonies. Because of its size and significance, it has attracted local and international funding over time. Moreover, because of its so-called "scientific management" and the reputation of its products, it received a loan from the World Bank in 1976 and again in 1982. ${ }^{20}$ The Sao Hill Forest is historically important to the Tanzanian government, bringing in foreign exchange equivalent to 55,000,000,000 Tanzanian Shillings $\left(23,913,043.5\right.$ US $\$$ ) per year. ${ }^{21}$ The forest sector in the Ministry of Natural Resources and Tourism is the second greatest contributor of foreign exchange. Tanzania has various forests and woodlands: most prevalent is miombo in the middle and south, Acacia in the north, mangroves along the coast, and closed-canopy forests in the mountains of the west - but about 12.5 million hectares lie within gazetted Forest Reserves (of which 90 per cent are National Forest Reserves and the rest are Local Authority Forest Reserves), and about 19 million hectares lie in unreserved forests (village or common land). ${ }^{22}$ Generally, the forestry sector is important in Tanzania as

14. A. Ahlback, Forestry for Development in Tanzania (Swedish University of Agricultural Sciences, International Rural Development Centre, Uppsala, 1988).

15. P. Jacovelli, "The Future of Plantations in Africa", International Forestry Review, 16, 2, 2014, p 149.

16. World Bank, Tanzania: Sao Hill Forestry Development Project (World Bank, Washington, D.C., 1983).

17. A.W. Hurst, "Not Yet out of the Woods: A Political Ecology of State Forest Policy and Practice in Mainland Tanzania, 1961-1998”, D. Phil., University of Oxford, 2004.

18. Ahlback, Forestry for Development.

19. World Bank, Sao Hill Forestry Project, Phase II, Project Completion Report, Tanzania (World Bank, Washington, D.C., 1992), p 17.

20. Kangalawe, "Plantation Forestry in Tanzania”, pp 129-143.

21. Interview with the manager-Sao Hill Forest Project, 27 January 2017.

22. J.F. Lund and O.J. Nielsen, "The Promises of Participatory Forest Management in Forest Conservation and Poverty Alleviation: The Case of Tanzania", L'Afrique Orientale, 2005, pp 201-241; and A. Akida and R. Blomley, "Trends in Forest Ownership, Forest 
it is estimated that it contributes US $\$ 2.2$ billion per year to the economy of Tanzania, which is equivalent to $20 \%$ of the Gross Domestic Product (GDP). ${ }^{23}$ In this context, Sao Hill is an important historiographical case study in the environmental history of Tanzania because it demonstrates state intervention on large-scale - economically (as noted above) and literally (135, 903 hectares) - although the land was customarily owned by villagers. It is useful to revisit the measures deployed by the state to take control of that land for planation forestry. Moreover, it is important to study such state intervention on the specific environment of Mufindi, which was initially a grassland. ${ }^{24}$ Adding to the utility of this case study, is that Sao Hill was established during the villagisation process whereby many people were resettled from their customary land to the nucleated villages - so this is helpful in understanding the environmental history and enduring power dynamics of such dispossession and land alienation.

From the mid-1980s there was a slow embrace of more decentralised measures to fix the hostile relationship between forest managers and local communities. To ensure Sao Hill survived, the concept of "community participation" was borrowed from the rubric of the "biodiversity paradigm", common in natural forest management. ${ }^{25}$ In Tanzania the paradigm influenced some key economic partners to shift from funding plantation forests to focusing funding efforts on natural forests - bringing severe funding crises to the plantation forests. ${ }^{26}$ Community participation in forestry management referred to programmes that consciously involved local people in its forest activities, which became widespread from the 1980s. ${ }^{27}$ The Ministry of Natural Resources in Tanzania defined the concept as strategies of involving communities and stakeholders in forest management. Before 1990 many of the so-called natural forests were placed in the "open access category", which rendered them vulnerable to encroachment by the surrounding communities. ${ }^{28}$ The World Bank's grim prophecy came true when production at the Sao Hill plantation came to a standstill in 1990 and then stagnated until 2006.

Resources Tenure and Institutional Arrangements: Are They Contributing to Better Forest Management and Poverty Reduction? Case Study from Tanzania" (Food and Agriculture Organisation, Rome, 2006).

23. Y. Ngaga, "Forest Plantations and Woodlots in Tanzania", African Forest Forum Working Paper Series, 1, 16, 2011, p 70.

24. See, for example, W. Beinart, "Soil Erosion, Conservation and Ideas about Development: A Southern African Exploration, 1900-1960", Journal of Southern African Studies, 11, 1, 1984, pp 52-83.

25. Sunseri, Wielding the Ax: State Forestry and Social Conflict in Tanzania, 94-95.

26. G.C. Kajembe, V.B.M.S. Kihiy, A.Y. Banana, W. Gombya-Ssembajjwe, and P. Ongugo, Community Participation in the Management of Protected Forest Areas in East Africa: Opportunities and Challenges (Sokoine University of Agriculture, Morogoro, 2010), pp 2-3.

27. Interview with Fidelis Mwanalikungu, Sao Hill Headquarters, Mufindi, 28 January 2016.

28. Interview with F. Mwanalikungu, Sao Hill Headquarters, Mufindi, 28 January 2016. 
We explain how this happened and examine the survival strategies adopted by the managers at the plantation in the absence of World Bank money, on which they had come to rely. We then explore the shifting relationship of the forest and the surrounding communities. We analyse diverse community reactions and responses to the implementation of what came to be understood as "participatory forest management".

We use archival sources from the Sao Hill plantation headquarters in Mufindi, the Tanzania National Archive, and oral sources gathered from the officials in the Ministry of Natural Resources in Dar es Salaam, as well as from officials and villagers from Iringa and Mufindi districts. ${ }^{29}$ Some of the officials from these districts, in addition to taking part in interviews, were willing to provide us with some key policy documents, which are otherwise unavailable for academic perusal. From these sources two significant themes emerged: the survival strategies adopted by the Sao Hill plantation and the land contestations between the state and private developers.

Fundamentally, we offer a story of resilience and pragmatic choices: the Sao Hill managers were compelled to adopt - albeit unevenly - a form of community participatory forest management for tactical reasons in the wake of the withdrawal of World Bank funding. The refusal of the World Bank to provide funding came at a time when there was local population pressure, active encroachment from surrounding villages, and the demand for land from the private sector. However, as we shall show, while the discourse of participatory management was deployed, it was implemented unevenly and, in some places, it was not implemented at all. ${ }^{30}$ In fact, the state retained control of the key aspects that defined community participation in the Sao Hill plantation.

29. The data for this article were obtained through archival sources and oral interviews. The archival sources were researched at the Tanzania National Archive (hereafter TNA) in Dar es Salaam and at Sao Hill Forest Plantation Headquarters in the Mufindi district between 2016 and 2017. Interviews were conducted in Mufindi district and in Dar es Salaam between 2015 and 2016. In focusing on this case study, we faced some challenges. A major hurdle was the inherent nature of bureaucracy wielded by the state in Tanzania. Despite being in possession of a University of Dar es Salaam research permit, we were not permitted to conduct research until the Ministry for Natural Resources and Tourism had granted its own permit. This was because Sao Hill is one of the most sensitive assets in the ministry. Secondly, given the recency of the period under review, we relied on the official reports and documents from officials in the field rather than archival resources. However, we offset this issue by triangulating with oral interviews from our fieldwork and other secondary sources.

30. Kajembe et al., Community Participation in the Management of Protected Forest Areas in East Africa, pp 2-3; L. Isager, I. Theilade and L Thomson, People's Participation in Forest Conservation: Considerations and Case Studies (Food and Agriculture Organisation, Rome, 2000), p 2. 


\section{Policy and programme reforms in the Ministry of Natural Resources}

Economic liberalisation and its raft of concomitant socio-economic reforms were introduced at the end of President Hassan Mwinyi's regime in 1995. From the parastatals these reforms trickled down to the Ministry of Natural Resources. The Ministry aimed at bringing in policies that embraced so-called sustainable forest management, as enshrined in the 1992 Rio Declaration on Environment and Development, 31 premised on the idea that the conservation of trees would be sustainable only if the needs of the surrounding communities were met. The main pressure for reform came from the World Bank and International Monetary Fund (IMF) under the structural adjustment programmes (SAPs). ${ }^{32}$ The trend of decentralising the Forestry Department went hand in hand with a broader process of decentralisation and the devolution of the political departments to regional, district and village levels. This overarching aim of decentralisation was part of the implementation of the World Bank and IMF policies, which discouraged central government monopoly of the power at the expense of the local governments and the private sector. ${ }^{33}$ The World Bank and IMF policies aimed ostensibly at making the local governments and private sector participate fully in the economic development of the country. Similarly, participatory forest management was promoted as the best way to ensure simultaneous local ecological diversity and the involvement of rural people, making them key partners in addressing both environmental and poverty-related problems. ${ }^{34}$ The Ministry of Natural Resources and Tourism (MNRT) responded to decentralisation by introducing policies and laws in the forest sector that appeared to represent participatory forest management. 35 The state created a National Forestry Policy in 1998, implemented through the Forest Act of 2002, to promote Community-based Forest Management (CBFM) through the establishment of Village Land Forest Reserves (VLFRs), where

31. United Nations Organisation, The Rio Declaration on Environmental and Development (1992), pp 4-6; World Bank, Opportunities and Challenges in the Forest Sector World Bank, Washington, 2002), pp 3-5.

32. A. Levine, "Convergence or Convenience? International Conservation NGOs and Development Assistance in Tanzania", World Development, 30, 6, 2002, pp 1048-1053; J. Shelter, Imagining Serengeti, A History of Landscape Memory in Tanzania from Earliest Times to the Present (Ohio University Press, Ohio, 1999), pp 223-230.

33. See Payer, "Tanzania and the World Bank", pp 809-810; G. Hyden and B. Karlstrom, "Structural Adjustment as a Policy Process: The Case of Tanzania", World Development, 21,9, 1993, pp 1396-1397; Sunseri, Wielding the Ax: State Forestry and Social Conflict in Tanzania, 94-95; K.E. Svendsen, "Development Strategy and Crisis Management", in C. Legum and G. Mmari (eds), Mwalimu: The Influence of Nyerere (James Currey, London, 1995), pp 108-124.

34. E. Zahabu et al., Forestland Tenure Systems in Tanzania: An Overview of Policy Changes in Relation to Forest Management (Department of Ecology and Natural Resource Management, Norwegian University of Life Sciences, 2009).

35. Zahabu et al., Forestland Tenure Systems in Tanzania: An Overview of Policy Changes in Relation to Forest Management, pp 13-17; P. Kaiser, "Structural Adjustment and the Fragile Nation: The Demise of Social Unity in Tanzania", The Journal of Modern African Studies, 34, 2, 1996, pp 231-232. 
communities became both "managers and owners", as well as through Joint Forest Management (JFM), where "local communities co-manage forests with the designated authorities of National or Local Government Forest Reserves". The Forestry and Beekeeping division declared:

CBFM is a power-sharing strategy. [...] It aims to secure forests through sharing the right to control and manage them, not just the right to use or benefit from them. Therefore, CBFM targets communities not as passive beneficiaries, but as forest managers. ${ }^{36}$

This makes it evident that the Tanzania National Forestry Policy certainly advocated community empowerment in forest management, even if this was not as evident in practice.

One of the major catalysts of change was to raise awareness of the essential linkages between the environment and development. ${ }^{37}$ On a macro-economic level, the policy was intended to reduce direct government involvement in production, thereby creating an enabling environment for a strong private sector. This was a fundamental and profound change, uprooting old ideas of top-down, and state-directed management integral to Tanzanian socialism - ujamaa. The 1998 National Forest Policy followed this decentralising trend by proposing reduced state investment in plantation forestry by encouraging and accommodating the private sector. However, as we shall argue, the implementation of these policies on the ground, with respect to Mufindi district, left a great deal to be desired.

The National Forest Policy was cemented by the National Forest Programme, which was promulgated in late 2001. The first item on the agenda of the National Forest Programme was participatory forest management, with a particular focus on the social dimension of gender. Participatory forest management of resources was argued to be a panacea for rectifying the gender imbalance in the economy overall and in the forest sector specifically. ${ }^{38}$ The strategies that were employed to resolve these shortcomings were slightly modified "community-based forest management" (CBFM) and "joint

36. The United Republic of Tanzania, Ministry of Natural Resources and Tourism, Forest and Bee Keeping Division, Community based Forest Management Guidelines for the Establishment of Village and Forest Reserves and Community Forest Reserves (Dar es Salaam, 2007), p 2. However, Community Based Forest Management (CBFM) has been implemented mainly in miombo woodland - outside state forest reserves and on village land.

37. The United Republic of Tanzania, Ministry of Natural Resources, National Forestry Policy (Dar es Salaam, 1998), p 8.

38. K. Hamza and E. Kimwer, Tanzania's Forest Policy and its Practical Achievements with Respect to Community Based Forest Management in MITIMIOMBO (Tanzania Association of Forests, Morogoro, 2003), pp 30-31; G. Monela and J. Abdallah, "Dynamism of Natural Resource Policies and their Impact on Forestry in Tanzania", in K. Havnevik and A Isinika (eds), Tanzania in Transition: From Nyerere to Mkapa (Mkuki na Nyota, Dar es Salaam, 2010), pp 159-174. 
forest management" (JFM). ${ }^{39}$ These programmes employed by the Ministry on the ground, operated in tandem with measures entailing collaborating with local governments in the management of forests in the general lands and local government forest reserves. ${ }^{40}$ CBFM and JFM were not applied directly, as in natural forests, because the Sao Hill took the principles of participatory forest management and forged them into a form of "corporate social responsibility" towards the villages surrounding the plantation. ${ }^{41}$ This new relationship between Sao Hill management and the adjacent communities was evinced through improvement of public infrastructure and raising "forest awareness". The villages received road maintenance, school buildings and medical dispensaries, while the Sao Hill received community help in protecting the forest from fire, land encroachment and wood poachers.

These measures came at a time when the Ministry of Natural Resources admitted that the plantation forests lacked funds from the state or international donors to manage the plantation, let alone increase its productivity. ${ }^{42}$ On a very basic level, without this new relationship between forest managers and local villagers, the plantation faced a severe threat of fire. ${ }^{43}$ Moreover, the net planted area and growing stock were declining in terms of area and quality. Indeed from 1996 to 2000, there was no planting programme because of a dire shortage of funds and lack of state interest. The management conceded openly that "there was no political will in those years". ${ }^{4}$ The failure to extend the plantation in this period was due to the absence of funds from the World Bank loans, which had ended officially in 1992 as noted, but was also due to mismanagement of funds received from the sale of logs. 45

As a drastic intervention, the Sao Hill plantation and the Ministry of Natural Resources introduced the Logging and Miscellaneous Deposit Account (LMDA) in 2000. LMDA retained funds generated from state-owned forest plantation amounting to about $45 \%$ of the forest's royalties to service silvicultural and road maintenance activities in the plantations. ${ }^{46}$ This was aimed at increasing internal revenues from the

39. The United Republic of Tanzania, Ministry of Natural Resources, National Forest Programme in Tanzania, 2001-2010 (Dar es Salaam, 2001), p 23.

40. United Republic of Tanzania, National Forestry Policy, Ministry of Natural Resources (Dar es Salaam, 1998), p 8.

41. Interview with Fidelis Mwanalikungu, Forest Surveillance Section, Sao Hill Headquarters, 27 March 2016.

42. Republic of Tanzania, MNR, Forest Programme, 2001-2010, p 23.

43. Interview with Joseph Sondi, Surveillance Section, Sao Hill Headquarters, 26 January 2017.

44. Interview with Fidelis Mwanalikungu, Surveillance Section, Sao Hill Headquarters, 27 March 2016.

45. The formal name of such funds is the "stumpage". It can be estimated by calculating the number of hectares of trees to be harvested.

46. Republic of Tanzania, MNR, National Forest Programme in Tanzania, 2001-2010, p 23; Ngaga, "Forest Plantations and Woodlots in Tanzania", African Forest Forum Working Paper Series, 1, 16, 2011, pp 17 and 50; and Interview, J. Sondi and F. Mwanalikungu, Surveillance Section, Sao Hill Forest Headquarters, 26 January 2017. 
forest products and services. At Sao Hill the LMDA was credited with having increased revenues tremendously. It was estimated by the Sao Hill management that the LMDA brought in between 8 and 11 billion Tanzanian shillings, ${ }^{47}$ depending on the annual allowable cut (AAC) per year. ${ }^{48}$ The AAC refers to the mature forests and are due for harvesting in the year, measured in cubic metres.

Until 2009, the mean allowable cut at Sao Hill plantation reached $1035 \mathrm{~m}^{3}$ annually. ${ }^{49}$ The LMDA came in to rescue them from financial crisis, because all revenue was deposited into the central government's treasury account. The money collected in the central treasury from logging was no longer disbursed back to the plantation for further production. Thus, it was not the state's failure to fund the plantation but rather the state's shameless rent-seeking predation on the plantation, that led to the sector's collapse. ${ }^{50}$

\section{"It takes a village": Community in the "participatory forest management model"}

The Sao Hill management helped the surrounding villages in a working (if uneven) partnership in the early 2000s. The plantation administration made a point of developing this mutualism with the surrounding communities - with the main aim of curbing the outbreak of fires. It applied the participatory forest management model by assisting villages materially and by outreach education programmes on fire control, community health, and agricultural initiatives, like bee keeping. ${ }^{51}$

The plantation management increased the concentration of activities in the surrounding villages between 2010 and 2013. It was reported that cases of fire declined rapidly in the same years as the villagers in the adjacent areas began to rely on the assistance from the plantation bosses. The reduced incidence of fire seemed to indicate that material support to the surrounding villages was working and - from our interviews - it appears that the villagers also felt that activities of the Sao Hill Forest were to their mutual benefit. ${ }^{2}$ In fact, what the plantation was doing was taking over the services previously offered to the villagers by the state. The 2010/2011 period for example, ended with assistance to four villages, namely Kitasengwa, Itimbo, Ihalimba and Nyololo. For the relevant figures, see Sao Hill Plantation Forest Archive (SHPFA) Table 1.

47. This amount was equal to 4, 400,000 US dollars.

48. Interview, J. Sondi, Surveillance Section, Sao Hill Forest Headquarters, 26 January2017.

49. Ngaga, "Forest Plantations and Woodlots in Tanzania", pp 17 and 50.

50. Interview, F. Mwanalikungu, Surveillance Section, Sao Hill Headquarters, 27 March 2016.

51. Interview, F. Mwanalikungu, Surveillance Section, Sao Hill Headquarters, 27 March 2016.

52. Interview, Gaitan Kalole, chairman of Ihalimba Village, Ihalimba, 19 April 2016. 
Kangalawe and Swart - From state monopoly to participatory forest management

\begin{tabular}{|l|l|l|l|}
\hline Village & Details of assistance & Cost in US \$ & Division \\
\hline Kitasengwa & Village government office construction & 2498.532 & 4 \\
\hline Itimbo & Building of a house for the village doctor & 2483.31 & 3 \\
\hline Ihalimba & Village dispensary construction & 2473.575 & 3 \\
\hline Nyololo & Village dispensary construction & 2488 & 2 \\
\hline
\end{tabular}

Table 1: Villages assisted by the Sao Hill Forest, 2010/2011 (SHPFA).

The village leaders readily admitted appreciating the support they received from the Sao Hill plantation management but felt that they had offered as much in return. The change in the relationship was rapid and radical: they came to believe that the Sao Hill Forest had become an equal partner to the villagers in almost all sectors. ${ }^{53}$ The discourse was of "good neighbours" and shared dependence on each other. Gaitan Kalole, the chairman of the Ihalimba Village, for example, said: “...the villagers at Ihalimba depend on the Sao Hill Forest for many things, such as assistance on fire outbreaks on their woodlots." He added that the management sometimes relied on the help of villagers to put out wildfires and that this service was offered free of charge because of the good neighbourly relations they had built.

The Sao Hill management assisted four villages in 2011/2012, arguing that there was a direct connection between effective fire control and village assistance. 54 Their decisions were pragmatic and the discourse used was of the utilitarian "buying of a service", with rational triage evinced in more at-risk areas: for example, the villages in Division Three, which was prone to many fires, were given higher priority. See Table 2 below for the details of assistance provided in the 2011/2012 financial year.

\begin{tabular}{|l|l|l|l|}
\hline Village & Details of assistance & Cost in US \$ & Division \\
\hline Mkalala & Building primary school classes & 1749.5 & 1 \\
\hline Vikula & Building of a house for the village doctor & 2187.25 & 3 \\
\hline Wami & Village dispensary construction & 2234.5 & 3 \\
\hline Mninga & Building of classes at Mlimani primary school & 2400 & 1 \\
\hline
\end{tabular}

Table 2: Villages assisted by the Sao Hill Forest, 2011/2012 (SHPFA).

The villagers acknowledged that they benefited a great deal from the presence of the Sao Hill forest - sometimes in unexpected ways. At Mninga village, for example, one elder said that the forest project had reduced youth urban migration, because the youth could now find temporary jobs in the proximity of their homes. ${ }^{55}$ The district commissioner indicated that the services provided were a peace-making strategy. He said that the forest project distributed more than 1000,000 seedlings free of charge in

53. Interview, Gaitan Kalole, chairman of Ihalimba Village, Ihalimba, 19 April 2016.

54. Interview, F. Mwanalikungu, Surveillance Section, Sao Hill Headquarters, 27 March 2016.

55. Interview with Mathias Lema, Tanzania Forest Services Agency (hereafter TFS) Department, MNR Headquarters, Dar es Salaam, 22 May 2016. 
the surrounding villages. ${ }^{56}$ This helped the villagers to develop private village-run forests and individual woodlots. Thereby, the villagers gradually became part of the forest project: directly and indirectly. They were directly involved in putting out fires whenever they occurred because they were protecting their own woodlots. The result of these efforts was remarkable, reducing fire incidents to zero by $2015 .{ }^{57}$ The Sao Hill plantation management increased assistance to the surrounding villages in the financial year 2012/2013, as shown in Table 3.

\begin{tabular}{|l|l|l|l|}
\hline Village & Details of assistance & Cost in US \$ & Division \\
\hline Nundwe & Building of a house for the village doctor & 1578 & 3 \\
\hline Ibatu & Village dispensary construction & 626.25 & 2 \\
\hline Mwitikilwa & Village dispensary construction & 2310 & 3 \\
\hline Kasanga & Construction of 2 classes, an office and a store & 142.5 & 1 \\
\hline Changalawe & Building 3 primary school classes & 1785.755 & 2 \\
\hline Ugesa & Building 2 primary school classes \& 1 house & 2438 & 3 \\
\hline Kihanga & Building 2 classes for primary school & 1890 & 1 \\
\hline Ludilo & Construction of 2 teachers' houses & 524 & 3 \\
\hline Usokami & Building a village market & 275.6 & 3 \\
\hline
\end{tabular}

Table 3: Villages assisted by the Sao Hill Forest, 2012/2013 (SHPFA).

The assistance diversified over time. For example, at Nundwe village, the village executive officer said that the Sao Hill management helped them construct new office buildings for the village secretary. Furthermore, the forest management gave them a certain number of hectares to harvest free of charge. ${ }^{58}$ In 2015 his village was given a permit to harvest hectares equivalent to 200 cubic metres. ${ }^{59}$ The villagers felt this was a reversal of historical oppression - a kind of practical reparation. At a group interview at Nundwe village, Galafwata Kihongole and his fellow villagers said, "though the forest department took our fertile land under the pretext of villagisation in 1977, it is clear nowadays that the development we see in our village is directly linked to the presence of the plantation forest". 60

56. Interview, Jowika Kasunga, district commissioner, Mafinga Headquarters, 18 May 2016.

57. Interview, with Kasunga, district commissioner, Mafinga Headquarters, 18 May 2016.

58. Interview, Godfrey Mkongwa (aged 35 years), Village executive officer at Nundwe Village, 8 April 2016.

59. Logs are calculated in cubic metres because before harvesting the length and girth of the log is calculated.

60. Interview, Galafwata Kihongole (aged 62 years), Clemence Mhomanzi (aged 50 years), Gallen Mpangala (aged 65 years) and Augustine Mhomanzi (aged 51), at Nundwe Village, 6 April 2016. 
To assess how those adjacent villages were benefiting (or not) from the Sao Hill programme it is useful contrast them with the villages further away from the Sao Hill plantation forests. The Forest Officer in Iringa district (a district adjacent to Mufindi, which was not benefiting from Sao Hill services) said that they envied the Sao Hill project because it assisted the adjacent villages. He gave examples of villages like Mfukulembe and Kibena from the Iringa District, which had poor public social services, little health care and dilapidated school buildings, while the villages near the forest (such as Itimbo and Ihalimba) were well funded.61

\section{Burning issues: Fire control strategies in the adjacent villages}

Fire outbreaks have been one of the major threats to the sustainability of the Sao Hill plantation forest since its establishment in the late 1930s. In just one devastating blaze in 1983, for example, a fire claimed 6,498.3 hectares. ${ }^{62}$ Between 2000 and 2011 a total of 8,227.8 hectares worth 846 million Tanzanian shillings were burnt. ${ }^{63}$ On the other hand, between 2000 and 2011 the Sao Hill plantation managed to extinguish more than 143 fires. ${ }^{64}$ In 2010 the Sao Hill plantation conducted a survey and the results indicated that conflagrations were the result of intentional fires (that simply escaped control) from honey harvesting, ${ }^{65}$ farm preparation, hunting, and unintentional fires from loggers' camps, fishermen and herders, There were also incidents of deliberate arson by the alienated. 66 These anthropogenic causes had environmental drivers too: fires were exacerbated by high wind speeds in Mufindi, where the wind blows from east to west in the dry season between July and mid-November. However, despite the list of possible causes, in most cases fires in Mufindi were precipitated by land use practices. Fire was central to farm preparations between August and November in the adjacent villages.

To mitigate fire, firefighting methods were taught by the Sao Hill plantation. They first trained 25 of their own staff members by sending them to Johannesburg, South Africa, for a one-month short course on firefighting in 2010.67 When the staff members went back after the firefighting training, their first task was to revamp firefighting crews, and ensure the provision of firefighting equipment. What was

61. Interview, Prosper Njau, Iringa district Forest Officer, at Iringa district headquarters, on 14 May 2016.

62. TNA, File: FD/33/23/8, E.M. Ntumbo and S.M. Malya "Rehabilitation of Burnt plantations at Sao Hill Forest Project" October 1984, Acc. No. 604: Sao Hill Forest Project.

63. Interview, Fidelis Mwanalikungu, Sao Hill Forest Surveillance Section, Sao Hill Headquarters, 27 March 2016.

64. Interview, F. Mwanalikungu, Surveillance Section, Sao Hill Headquarters, 27 March 2016.

65. The traditional method of honey harvesting is through fire smoking.

66. Interview, F. Mwanalikungu, Surveillance Section, Sao Hill Headquarters, 27 March 2016.

67. Interview with Fidelis Mwanalikungu, Surveillance Section, Sao Hill Headquarters, 27 March 2016. 
significant was that aside from fire-fighting, they were tasked with maintaining good social relationships with the adjacent villages, despite some long-standing differences and covert hostility.

At the heart of the firefighting strategy was the standby crews. This group comprised male youths and was similar to any police unit. The group came into the camps from July to early December yearly. Table 4 shows the distribution of the fire crews per forest division in the Sao Hill plantation forest.

\begin{tabular}{|l|l|l|l|l|l|}
\hline Sn & Area/Division & Location Name/Village & $\begin{array}{l}\text { Fire crew } \\
\text { groups }\end{array}$ & Average & $\begin{array}{l}\text { Total } \\
\text { personnel }\end{array}$ \\
\hline 1 & I & Irundi & 2 & 21 & 42 \\
\hline 2 & II & Matanana, Ihefu & 2 & 23 & 46 or 47 \\
\hline 3 & III & $\begin{array}{l}\text { Mwitikilwa, Kilosa, Ilasa, } \\
\text { Itimbo, Ihalimba and Vikula }\end{array}$ & 6 & 15 & 90 \\
\hline 4 & IV & Luiga, Kitasengwa & 2 & 21 & 42 or 43 \\
\hline 5 & Villages & $\begin{array}{l}\text { Kitasengwa, Itimbo, Mtili, } \\
\text { Matanana and Kihanga }\end{array}$ & 1 & 10 & 50 \\
\hline
\end{tabular}

Table 4: Fire crews' distribution in the Sao Hill plantation per division/village (SHPFA).

To ensure that fire suppression was sustainable, every range officer and sub-division manager was equipped with walkie-talkies, especially from July to December each year. Each fire tower was also provided with a bicycle. New fire towers were constructed at Kifumi, Kilosa, Ilasa and Sawala, to send reports from high-risk fire areas. ${ }^{68}$ Training the villagers in fire control systems, while still assisting them materially was thought to be the best method to protect the forest - and to ensure a mutual relationship in which both parties benefited. Education initiatives roped in about 50 villagers per programme. The topics varied and so did the educators: they included foresters, agriculturalists, veterinary officers, bee keeping experts, medical doctors, teachers, religious leaders, as well as the district commissioner's representatives and councillors. ${ }^{69}$

The forest official who organised the training explained that he taught the villagers about fire control methods. He told them that before lighting fires when burning grasses for cattle grazing or farm preparation, they were to report to the nearby forest station. Depending on the human resources at its disposal, the forest station would then arrange a time for clearing farms by lighting fires. The forest stations provided a company of six to ten men armed with fire-extinguishing equipment. The forest educator also made the point that sometimes it was not

68. Interview with Fidelis. Mwanalikungu, Surveillance Section, Sao Hill Headquarters, 27 March 2016.

69. Sao Hill Plantation Forest Archive (hereafter SHPLA), File No. MU/12.13/IV Vijiji vya Ujamaa (Socialist Villages) Forest Publicity Official to Sao Hill Forest Manager, "Supported Villages/2014/2015 by the Sao Hill plantation Forest", 10 August 2015. 
necessary to report to the forest station if it was too far away. If this was the case, the villagers were to approach the village executive officers in their respective villages. These officers had at their disposal experienced men who had attended fire training and control courses to assist them. Every village had ten people trained in managing fires. ${ }^{70}$ There was no charge to get assistance from these men, but sometimes the owners of farms provided a local brew as a liquid thank you. ${ }^{71}$

Any villager who started a fire without permission from the local authorities was fined. This was the only "stick", in a programme of "carrots" - and even so, it was the village (not the state, or the plantation) that benefited. At Kihanga village, for example, the culprit was obliged to pay two bags of cement and 1000 burnt bricks into a communal "kitty"per event. ${ }^{72}$ These material things were additional to what was prescribed as "table negotiation" fines, which amounted to 25,000 Tanzanian shillings. ${ }^{73}$ These fire-fighting initiatives met with great success. There was an astonishing decline in fire events, which numbered 143 in 2000, then 4 outbreaks in 2011 and finally zero in 2012. ${ }^{74}$ The Sao Hill forest management encouraged further education on making beehives and sometimes the management made and distributed them to the villagers free of charge. For example, in 2014/2015 Malangali Secondary School, one of the oldest secondary schools in Tanzania, was given 5 free beehives. ${ }^{75}$ Knowledge about beehives was important to stop the people from nearby villages from trespassing into the forest to take honey. To prevent this, free beehives were to become a central theme of providing those in adjacent villages with honey without depending on the Sao Hill forest. ${ }^{76}$

To make villagers more self-reliant in this new economic context, the Sao Hill management taught the local people ways to develop their own tree nursery for raising funds. Some villagers formed small organisations to develop tree nurseries in an advanced way similar to that of the Sao Hill plantations. The Sao Hill plantation management then acted as a patron to these growers' groups. Some of the groups were Hewa Safi (Clean Air) based at Mafinga town, the Imehe Women's Group based at

70. Interview with Fidelis Mwanalikungu, Sao Hill Forest Surveillance Section, Sao Hill Headquarters, 27 March 2016.

71. Interview with Raphael Lutumo (aged 70) at Ihalimba village 24 April 2016.

72. Interview with Fidelis Mwanalikungu, Sao Hill Forest Surveillance Section, Sao Hill Headquarters, 27 March 2016.

73. Interview with Madeusi Chelesi (72 years old), Mninga village, 14 April 2016.

74. Interview with Fidelis Mwanalikungu, Sao Hill Forest Surveillance Section, Sao Hill Headquarters, 27 March 2016.

75. SHPFA, File No. MU/12.13/IV Vijiji vya Ujamaa (Socialist Villages), Forest Publicity Official to Sao Hill Forest Manager, "Supported Villages/2014/2015 by the Sao Hill plantation Forest", 10 August 2015. In the years between 2007 and 2010 free beehive distribution benefited Mtula, Mtili, Kitilu, Matanana, Kitasengwa and Itimbo villages. See interview with Fidelis Mwanalikungu, Sao Hill Forest Surveillance Section, Sao Hill Headquarters, 27 March 2016.

76. Interview with J. Kasunga, District Commissioner, Mafinga Headquarters, 18 May 2016. 
Nyololo village, and the Ogopa Moto (Beware of Fire) group based at Kihanga village. ${ }^{77}$ To promote these groups and individuals financially, the forest management sometimes bought their tree seedlings and either planted them in its extension areas or distributed them to the villagers free of charge. However, these groups and individuals also sold to private customers from individual forest growers. ${ }^{78}$

\section{Seeing the wood for the (free) trees?}

As privatised tree selling became more lucrative, food security suffered. Mwanalikungu, one of the patrons of these groups, said that developing tree seedlings was one of the more profitable businesses conducted by the villages adjacent to the forest. However, a negative spin-off was that it reduced the area of land that was used for food crops in Mufindi and increased land grabbing, as everyone in Mufindi wanted to have his or her own woodlot. ${ }^{79}$ The district commissioner, who by virtue of his title, was the chairman of the Mufindi District Peace and Security Committee, was quoted saying "people in Mufindi district have planted trees everywhere even on their farms where they used to plant food crops".80 Capitalism proved more enticing than subsistence farming and the local district commissioner fretted that famine might follow this trend. He felt he had to impose a by-law to force every household to divide its land into sections for food crops, forestry and grazing land. He said that without such stern measures the district was likely to be plunged into a food crisis. ${ }^{81} \mathrm{An}$ agroforestry professor from Sokoine University of Agriculture concurred. Luther Lulandala was quoted as saying "agroforestry is the panacea for all problems related to fire woods and hunger, as everyone will produce the two items at his/her farm". ${ }^{82}$ The comments by the district commissioner and the agroforestry professor imply that - counter-intuitively - education on tree planting could, in some contexts, have negative outcomes that compromised food security.

When the villagers were asked about their excessive planting of exotic trees especially pines - in their food crop farms, they responded that their land was exhausted and the staple food crops they produced, maize and beans, had a lower market value than timber. ${ }^{83}$ The other reason shared by many villagers was that the Sao Hill plantation forest offered a safe reservoir for wild animals - especially monkeys,

77. Interview with Fidelis Mwanalikungu, Sao Hill Forest Surveillance Section, Sao Hill Headquarters, 27 March 2016.

78. The price of one tree seedling was between 100 to 200 Tanzanian shillings. Interview with Jowika Kasunga, District Commissioner, Mafinga Headquarters, 18 May 2016.

79. Olwig, M.F., Noe, C., Kangalawe, R. and Luoga, E., Inverting the Moral Economy: The Case of Land Acquisitions for Forest Plantations in Tanzania, Third World Quarterly, 36, 12, 2015, pp 23.

80. Interview, J. Kasunga, district commissioner, Mafinga Headquarter, 18 May 2016.

81. Interview, J. Kasunga, district commissioner, Mafinga Headquarter, 18 May 2016.

82. Interview with Prof. Luther Lulandala, Sokoine University of Agriculture, Morogoro Region, 7 January 2016.

83. Interview, Godfrey Mkongwa (aged 35 years), village executive officer at Nundwe Village, 8 April 2016. 
baboons, and wild pigs - who were now eating their crops. ${ }^{84}$ The villagers were not allowed to hunt these wild animals in efforts to protect their crops, because the rules of the forest reserves prohibited hunting. The villagers argued that they were thus forced to convert their food farms into woodlots contiguous with the Sao Hill plantation out of fear of such animals destroying their crops. One elder was lamented that they were not even allowed to enter the forest to hunt down these animals unless they acquired permits from the Sao Hill forest management. He complained: “... if you have a food crop farm in the area bordering the Sao Hill forest, you will have to sleep there as in the day you will have to ward off monkeys and baboons and in the night, you will have to ward off wild pigs". ${ }^{85}$ Thus, for some, the switch away from subsistence farming was not the lure of capitalism, but was rather a rational and strategic choice in the context of an environment altered by their own farming and their neighbour's plantation.

Moreover, the plantation management began to allow the adjacent villagers to practise "taungya agriculture". ${ }^{6}$ This is the system whereby villagers and forest staff were given the right to cultivate food crops in the clear-felled plantation forests land during the early stages of establishing the plantation forest. Cultivation was allowed to continue until, because of canopy closure, the trees shaded the crops. The taungya system is a historical legacy from Burma/Myanmar in which peasants were allowed to cultivate in the logged forests. The British introduced the system in 1950 to deal with shortage of land and labour in some regions like Tanga and Coast. ${ }^{87}$ It was deeply resented by the peasants from the Coast because they were evicted when the trees reached three years of age (the stage when a canopy is formed by the trees). ${ }^{88}$

The aim of the taungya system was to assist the landless people to cultivate food crops, while at the same time weed and protect the young trees. ${ }^{89}$ Between 2000 and 2015 taungya in the Sao Hill plantation forest was practised on almost all ranges where trees had been felled. ${ }^{90}$ The plantation forest staff and the villagers around the plantation were allocated plots in the areas where trees had been felled. They were

84. Interview with Kambaulaya Mtavangu, Mtili Village, 20 May 2016.

85. Interview with Kambaulaya Mtavangu, Mtili Village, 20 May2016.

86. O. Ndomba, et al., "Perils of Taungya to the Productivity of Forest Plantations and Need for Modification: Case Study of Meru Forest plantations in Tanzania," International Journal of Agriculture and Forestry, 5, 5, 2015, pp 267-275; E. Dean, "Birds of One Tree: Participatory Forestry and Land Claims in Tanzania”, Human Organization, 70, 3, 2011, pp 300-309.

87. Sunseri, Wielding the Ax: State Forestry and Social Conflict in Tanzania, 94-95.

88. Sunseri, Wielding the Ax: State Forestry and Social Conflict in Tanzania, 94-95.

89. Sunseri, Wielding the Ax: State Forestry and Social Conflict in Tanzania, 94-95; V. Agyeman Revising the Taungya plantation System: New Revenue-Sharing Proposals from Ghana (Republic of Ghana, 2011), pp 1-8; J. Evans and J. Turnbull, Plantation Forestry in the Tropics (Oxford University Press, Oxford, 2004), pp 320-321.

90. SHPFA, File No. MU/12.13/IV Vijiji vya Ujamaa (Socialist Villages), Forest Publicity Official to Sao Hill Forest Manager, "Supported Villages/2014/2015 by the Sao Hill plantation Forest”, 10 August 2015. 
permitted to cultivate annual crops, in this case maize and beans, and at the same time they took care of the young replanted trees. The villagers appreciated this plan whenever they were given the plots. ${ }^{91}$

However, local nepotism shaped this initiative. At Sao Hill plantation the forest officials and their families took the lion's share of the land allocated for taungya whenever the opportunity arose. The management then allotted a certain number of acres of farms with felled trees to the adjacent village leadership, who parcelled it out to individual villagers. ${ }^{92}$ There were thus obvious inequalities in the distribution of the plots to the villagers, which led to disaffection and alienation. ${ }^{93}$ Yet taungya in Mufindi nevertheless offered the villagers some aid and stopped fires and encroachment. ${ }^{94}$ Thus the Sao Hill forest management maintained an imperfect, uneven but enduring mutualism with the residents of adjacent villages for the sake of socio-environmental sustainability.

\section{"Everyone is becoming a forester in Mufindi": The woodlot developers in the adjacent villages}

We have shown how villagers shifted away from subsistence farming to embrace their own mini-plantations. Soon the district commissioner of Mufindi district reported that the income of the people, specifically those in the villages adjacent to the Sao Hill forest, was being directly or indirectly connected to forest products or non-timber forest products. The district commissioner explained to the authors: "...everyone in Mufindi district is a forester knowing or unknowingly" (our emphasis). ${ }^{95} \mathrm{He}$ was referring to the extent that the principles of forestry were employed by the people in Mufindi. As some of the residents in villages adjacent to the Sao Hill plantation were developing their own woodlots, ${ }^{96}$ others were working as agents for urbanites who suddenly wanted to buy land for developing new woodlots in their villages. Equally important, some villages were selling their woodlots with trees that were five or more years old, to the urbanites when they were pressed by immediate financial problems. Jacovelli referred to this situation of hunting land for planting trees as the undefined "new wave of investors in the forestry sector". ${ }^{97}$ Furthermore, the lumbering industry employed people from all sectors in Mufindi. There were big timber traders who owned saw mills based at Mafinga town. ${ }^{98}$ These big timber traders employed drivers who drove trucks

91. Interview with Raphael Lutumo (aged 70) at Ihalimba Village 24 April 2016.

92. Interview with Joseph Sondi, Sao Hill Forest Surveillance Section, Sao Hill Headquarters, 26 January 2017.

93. Interview with Fidelis Mwanalikungu, Sao Hill Forest Surveillance Section, Sao Hill Headquarters, 27 March 2016.

94. Interview with Fidelis Mwanalikungu, Sao Hill Forest Surveillance Section, Sao Hill Headquarters, 27 March 2016.

95. Interview, Jowika Kasunga, District Commissioner, Mafinga Headquarter, 18 May 2016.

96. Interview, Jowika Kasunga, District Commissioner, Mafinga Headquarter, 18 May 2016.

97. Jacovelli, "The Future of Plantations in Africa", 149.

98. Interview, George Mwagala, Timber trading centre at Mafinga, 18 May 2016. 
for hauling logs from the harvesting sites to the saw mills or camp sites. The drivers were assisted by an army of loaders and in the harvesting sites there was another army of experienced loggers. There were also women food vendors on the harvesting sites and at the saw mills. ${ }^{99}$

However, we focus on one group of beneficiaries of the Sao Hill plantation, because their case helps to explain our bigger argument about how and why villagers embraced private forestry from 2000 onwards. These are the woodlot developers in the villages adjacent to the Sao Hill forest. They were divided into two groups: those with little capital and technology, and those with the finance and the necessary equipment. For the most part, the first group comprised villagers who learnt about afforestation by observing what they saw in the Sao Hill plantation forest. The latter group mainly comprised successful timber traders who wanted to have their own plantation forests. They were predominately businesspeople although some were politicians and others were civil servants who invested their pension funds in the green gold of forests. 100 The woodlot developers formed by villagers who were connected to the Sao Hill plantation forests planted their trees on their customary land so they did not encroach on Sao Hill land for extension. Many of them had modest but productive woodlots of between 5 to 20 acres in size. ${ }^{101}$ An integral but little explored facet of the transition to woodlots, was the social status and new power they lent their owners: they produced social capital as well as actual capital. Thus, villagers and indeed, some forestry staff members in Mufindi district, were more than willing to reveal the size of their woodlots - they were proud because owning a woodlot implied social status. One village executive officer declared that "I was not born in this village but I have already lobbied the village elders to find me a piece of land, hence, last year I planted five acres of pine [Pines Patula] trees". ${ }^{102}$ Based on their perceptions, these villagers felt that it was a source of social shame for someone in the adjacent villages of the Sao Hill plantation to own nothing - even a humble two acres of trees was necessary to feel part of the new village social order. ${ }^{103}$

The villagers in the adjacent villages prepared their own seedlings. Some of them were subsidised with seedlings they received from Sao Hill forest. In terms of best practice for seedling preparation, theirs were of low quality in commercial terms. ${ }^{104}$ The spacing of trees in their woodlots was often ad hoc and disordered. These farmers depended on the education service provided by the Sao Hill plantation forest

99. Interview, Jowika Kasunga, District Commissioner, Mafinga Headquarter, 18 May 2016.

100. Jacovelli, "The Future of Plantations in Africa", p 149.

101. Interview with Raphael Lutumo (70 years) at Ihalimba Village 24 April 2016.

102. Interview with Godfrey Mkongwa (35 years), Village Executive Officer at Nundwe Village, 8 April 2016.

103. Interview with Godfrey Mkongwa (35 years), Village Executive Officer at Nundwe Village, 8 April 2016.

104. United Republic of Tanzania, Ministry of Natural Resources, Desk Study for Developing Mechanisms and Policies that Strengthen the Private Plantation Forestry and Related Value Chains (Dar es Salaam, 2014), 18. 
management under the programme of fire protection strategies. This was because state extension services were rare, not only for woodlots but also for food crops. ${ }^{105}$ The trees grown by these small-scale woodlot developers were harvested earlier than the minimum tenure, which is between 20 and 25 years. The villagers harvested the trees haphazardly and often desperately. One timber trading woman at Mafinga town explained: "... the villagers are forced to rape these young trees because they are pressed with financial problems like school fees for their children". She used the emotive term 'rape' to imply the young trees were prematurely - indeed, violently, wrongly, unnaturally - harvested by the villagers. ${ }^{106}$

A Ministry of Natural Resources spokesperson, Mathias Lema, insisted that the woodlot developers from the adjacent villages simply benefited from knowledge disseminated by the Sao Hill plantation by 'coincidence'. It was the unintentional negative 'blowback' of educating them. Their aim was never to make them fully-fledged foresters but at least to equip them with the low-level skills necessary to grow their own timber instead of pillaging Sao Hill. Lema said that before 2000 there was a tendency among the villagers to depend on the Sao Hill plantation for everything. ${ }^{107}$ Moreover, in understanding their liminal position in the newly-capitalist Tanzania, this category of woodlot developers was not recognised by financial institutions. The villagers could not access bank loans because their land was held under customary land ownership, which was either not legally recognised or the villagers had no knowledge of such registration. ${ }^{108}$

The second group of woodlot developers comprised the few people and companies who had capital and technology. The Green Resource Company was one of the private afforestation organisations in Tanzania, Uganda and Mozambique, which invested in Mufindi. The paper mill at Mufindi closed in 1997 and three years later a Norwegian company called Green Resources applied for land near Sao Hill and in 2003 it purchased and reopened Sao Hill Sawmill. ${ }^{109}$ This company became East Africa's largest sawmill, and also produced electrical poles. This was one the companies that received a certificate for carbon harvesting in Mufindi. It was the largest independent

105. Interview with Raphael Lutumo (70 years) at Ihalimba Village 24 April 2016.

106. Interview with Maula Chaula (51 years), Mafinga Timber Trading Centre, 18 May 2016.

107. Interview with Mathias Lema, TFS (Tanzania Forest Services Agency) Department, Ministry of Natural Resources Headquarters, Dar es Salaam, 22 May 2016.

108. United Republic of Tanzania, Ministry of Natural Resources, Desk Study for Developing Mechanisms and Policies that Strengthen the Private Plantation Forestry and Related Value Chains (Dar es Salaam, 2014), p 18; Interview with Godfrey Mkongwa (35 years), village executive officer at Nundwe Village, 8 April 2016.

109. M. Purdon, "Land Acquisitions in Tanzania. Strong Sustainability, Weak Sustainability and the Importance of Comparative Methods", Paper presented at World Bank Conference on Land and Poverty, Washington 23 to 26 April 2012; Green Resource Company Limited, "Reforestation in Grassland areas of Uchindile, Kilombero, Tanzania and Mapanda, Mufindi Tanzania" (Unpublished report, 2009), pp 2-3; B. Karumbidza and W. Menne, Potential Impacts of Tree Plantation Projects under the CDM: An African Case Study (Centre for Science and Environment, New Delhi, 2009). 
investor in the area adjacent to the Sao Hill plantation, with a 99-year lease on 18379 hectares. ${ }^{110}$ The Green Resource company was not a competitor to the Sao Hill plantation because it represented the key customers of the Sao Hill loggers. When the Sao Hill Saw Mill was privatised in 1996, some of the Norwegian expatriates bought the mill. Instead of sticking to just buying wood, they started planting trees. They provided employment to the Mapanda villagers. However, the company, was criticised by environmental experts who claimed that it was converting the grassland to eucalyptus forests and thereby destroying the ecosystem. Worse still, the land transfers in the villages were claimed to be exploitative because the company bought the land from the villagers who did not understand the value of land (at the time of buying in 2003).111 Some villages suffered severely from the rush for land by private companies and individual woodlot developers. At the beginning of the land rush some villagers thought that they had excess land and sold it cheaply, thinking it was idle land. The Green Resource Company and the Highland Forest Company at Mapanda village, for example, set a precedent for countless unregistered woodlot developers - there was a rumour circulating in the villages (and even in towns like Mafinga and Iringa) that the two companies would build a saw mill (at either Mapanda or Chogo village). The villagers were unaware of the true value of their land in the early 2000s and were thus exploited ruthlessly by the private companies and by individual woodlot developers. ${ }^{112}$

The other company is the Highland Forest plantation, a sub-company of Kundan Sing Construction based in Dar es Salaam. ${ }^{113}$ The company encroached on the Sao Hill plantation extension land reserves and had already planted 2500 hectares of eucalyptus trees. It allegedly acquired land through the corrupt leaders of Mapanda village in 2009. It quickly built houses for its workers, and, because of the remoteness of the area, built its own airdrome on one of its hills. However, the Third Division Forest manager stopped the development of this airfield and the plantation development because it transpired that all the land planted was within the Sao Hill extension areas. This company was one of the reasons behind the formation of the ministerial commission of inquiry on the encroachment status of the villages surrounding Sao Hill plantation forest in March 2012. Making the residents of adjacent villages participate in planting trees in their customary owned lands so that they could be part of protecting the Sao Hill plantation during fire occurrence, led to some villagers (who were not aware the exact boundaries between their lands and those owned by Sao Hill forest) sold a disproportionate amount of land to private investors. As a consequence,

110. Olwig et al., "Inverting the Moral Economy".

111. Karumbidza and Menne, Potential Impacts of Tree Plantation Projects under the CDM.

112. This fills the gap left by Olwig et al., who did not connect the problems of land encroachment at Mapanda and Chogo villages with the history of Sao Hill plantation. See M.F. Olwig, C. Noe, R. Kangalawe and E. Luoga, "Inverting the Moral Economy: The Case of Land Acquisition for Forest Plantations in Tanzania", Third World Quarterly, 36, 12, 2015, p 23.

113. Republic of Tanzania of Tanzania, Preliminary Ministerial Report on the Out growers, and Sao Hill Forest Reserves, Mufindi District (Government Printer, Dar es Salaam, 2012), p 13. 
the very villagers who were to be part of the protection of Sao Hill plantation inadvertently sold its expansion lands too. This meant that while many villages in the vicinity of Sao Hill plantation benefited from the services provided by the plantation, in other villages the exercise brought a suite of new problems with regard to land grabbing.

\section{Conclusion}

Participatory forest management has seen several successes in ecological and biodiversity recovery, fire prevention and effectual regimes of management on shoestring budgets. ${ }^{114}$ Yet programmes have also experienced corrupt or poor governance at village level and negative effects on forest environments. ${ }^{115}$ We have explored the survival strategies deployed by the Sao Hill management in the absence of World Bank funding between 2001 and 2015. Their tactics depended on the LMDA mechanism, pioneered by the Ministry of Natural Resources, to rescue the dwindling financial backing of plantations in the country. LMDA retained 45 percent of plantation forests revenues for steering production and reduced the Ministry of Finance's slow pace on disbursing the funds for developing the plantations. Internally, the Sao Hill plantation forest improved remarkably in its relationship with the adjacent villages by implementing practices of community forest management. However, this then unintentionally encouraged private sector involvement in the previously solely stateowned plantation sector, which triggered a rush for land and - ironically - increased encroachment on the forest. Participation by "local communities" does not ensure forest conservation is either apolitical or easy.

Primarily, we have presented a narrative of flexibility, resilience and down-toearth decisions: the Sao Hill managers were forced to adopt, and then radically adapt, a form of community participatory forest management. They did so for strategic reasons following the withdrawal of World Bank funding and mounting demographic pressure from surrounding villages, and pressure from the private sector for access to land. While the management policies are officially "participatory", the everyday operations of the forest are shaped by both the long history of community-state interaction and the current reality of the economic interested individuals.

While the rhetoric of participatory management was deployed it is clear that the central aim was to protect the Sao Hill plantation both as an ecological entity and as a financial concern, because the measures taken were geared at enticing the villagers to be part of the protection of the natural resources. Moreover, we need to accept the limited success of this venture, because while the outcome of the measures deployed by the forest management was celebrated by some villagers, others suffered as their

114. See Kajembe et al., Community Participation in the Management of Protected Forest Areas in East Africa, pp 2-3.

115. Brockington, "Forests, Community Conservation, and Local Government Performance"; and K. Schreckenberg and C. Luttrell, "Participatory Forest Management: A Route to Poverty Reduction? The International Forestry Review, 11, 2, 2009, pp 221-238. 
land was grabbed by the private forest developers - for them it was certainly a tragedy, but only limited the commons. This was an imperfect deployment of community-based natural resource management in a context that permitted plundering by private entrepreneurs while keeping the rhetoric (and some of the practical benefits) of "community management". Yet the context must be understood: the local management faced constraints upon their own agency. Instead of imposing a new paradigm they had to adapt one $a d$ hoc and apply it unevenly. In essence, in Sao Hill Forest, we see the uneasy union of Hardin and Ostrom.

Dynamic power relations between many actors - ordinary people, the powerful elite in local communities, local capitalists, expatriate entrepreneurs, forest managers and state officials in the city - have rendered forest resource management a fractured, fractious and multi-faceted process. We argue it is important to insert such an unusual case study (that looks at community involvement in a plantation, rather than natural, forest) into the broader scholarly conversation on forest management, suggesting that further research - especially studies of forests and their users over time - will buttress more effective policies in the future. The inevitable tragedy of the commons model has been challenged by evidence of time-honoured methods implemented by communities to use their environmental capital sustainably. In fact, there are examples of winners and losers for all ownership-use systems: state-owned, individual private property, and common property regimes. Historians can contribute to strategy making by helping move past the stereotype that there is a single normative model that solves all commons dilemmas. We can help establish which idiographic factors within the specific local context are most significant in rethinking natural resource regimes.

\section{REFERENCES}

Ahlback, A., Forestry for Development in Tanzania (Swedish University of Agricultural Sciences, International Rural Development Centre, Uppsala, 1988).

Akida, A. and Blomely, R., "Trends in Forest Ownership, Forest Resources Tenure and Institutional Arrangements: Are They Contributing to Better Forest Management and Poverty Reduction? Case Study from Tanzania" (Food and Agriculture Organisation, Rome, 2006).

Beinart, W., "Soil Erosion, Conservation and Ideas about Development: A Southern African Exploration, 1900-1960", Journal of Southern African Studies, 11, 1 (1984).

Bennett, B.M., "Locality and Empire: Networks of Forestry in Australia, India and South Africa, 1843-1948”, PhD thesis, University of Texas, Austin, 2010.

Blomley, T. and Ramadhani, H., “Going to Scale with Participatory Forest Management: Early Lessons from Tanzania, The International Forestry Review, 8, 1 (2006).

Brockington, D., "Forests, Community Conservation, and Local Government Performance: The Village Forest Reserves of Tanzania", Society and Natural Resources, 20, 9 (2007).

Campbell, H. and Stein, H. (eds), The IMF and Tanzania: the Dynamics of Liberalisation (Southern Africa Political Economy Series Trust, Harare, 1991). 
Dean, E., "Birds of One Tree: Participatory Forestry and Land Claims in Tanzania", Human Organization, 70, 3 (2011).

Degnet, M.B., Van der Werf, E., Ingram, V. and Wesseler, J.H.H., "Do Locals have a Say? Community Experiences of Participation in Governing Forest Plantations in Tanzania', Forests, 11, 7 (2020).

Evans, J. and Turnbull, J., Plantation Forestry in the Tropics (Oxford University Press, Oxford, 2004).

Gibson, C.C., Williams, J.T. and Ostrom, E., "Local Enforcement and Better Forests", World Development, 33, 2 (2005).

Hamza, K. and Kimwer, E., Tanzania's Forest Policy and its Practical Achievements with Respect to Community Based Forest Management in MITIMIOMBO (Tanzania Association of Forests, Morogoro, 2003).

Havnevik, K. and Isinika, A. (eds.), Tanzania in Transition, From Nyerere to Mkapa (Mkuki na Nyota, Dar es Salaam, 2010).

Hurst, A.W., "State Forestry and Spatial Scale in the Development Discourses of PostColonial Tanzania: 1961-1971", The Geographical Journal, 2003, 169, 4 (2003).

Hurst, A.W., "Not Yet out of the Woods: A Political Ecology of State Forest Policy and Practice in Mainland Tanzania, 1961-1998", D Phil, University of Oxford, 2004.

Hyden. G. and Karlstrom, B., "Structural Adjustment as a Policy Process: The Case of Tanzania”, World Development, 21,9 (1993).

Isager, L., Theilade, I., and Thomson, L., People's Participation in Forest Conservation: Considerations and Case Studies (Food and Agriculture Organisation, Rome, 2000),

Jacovelli, P., "The Future of Plantations in Africa", International Forestry Review, 16, 2 (2014).

Kaiser, P., "Structural Adjustment and the Fragile Nation: The Demise of Social Unity in Tanzania", The Journal of Modern African Studies, 34, 2 (1996).

Kajembe, G.C., Kihiy, V.B.M.S., Banana, A.Y., Gombya-Ssembajjwe, W. and Ongugo, P., Community Participation in the Management of Protected Forest Areas in East Africa: Opportunities and Challenges (Sokoine University of Agriculture, Morogoro, 2010).

Kangalawe, H., "Plantation Forestry in Tanzania: A History of Sao Hill Forests, 19392015", PhD thesis (Stellenbosch University, 2018).

Karumbidza, B. and Menne, W., Potential Impacts of Tree Plantation Projects under the CDM: An African Case Study (Centre for Science and Environment, New Delhi, 2009).

Levine, A., "Convergence or Convenience? International Conservation NGOs and Development Assistance in Tanzania", World Development, 30, 6 (2002).

Lopez, M.C. and Moran, E.F., "The Legacy of Elinor Ostrom and its Relevance to Issues of Forest Conservation", Current Opinion in Environmental Sustainability, 19 (2016).

Lund., J.F. and Nielsen, O.J., "The Promises of Participatory Forest Management in Forest Conservation and Poverty Alleviation: The Case of Tanzania", L'Afrique Orientale, (2005). 
Mgaya, R., "Forest and Forestry in Tanzania: Changes and Continuities in Policies and Practices from Colonial Times to the Present", Journal of the Geographical Association of Tanzania, 36, 2 (2016).

Monela, G. and Abdallah, J., "Dynamism of Natural Resource Policies and Impact on Forestry in Tanzania", in Havnevik, K. and Isinika, A. (eds.), Tanzania in Transition, From Nyerere to Mkapa (Mkuki na Nyota, Dar es Salaam, 2010).

Ndomba, O. et al., "Perils of Taungya to the Productivity of Forest Plantations and Need for Modification: Case Study of Meru Forest Plantations in Tanzania", International Journal of Agriculture and Forestry, 5, 5 (2015).

Ngaga, Y., "Forest Plantations and Woodlots in Tanzania", African Forest Forum Working Paper Series, 1, 16 (2011).

Olwig, M.F., Noe, C., Kangalawe, R. and Luoga, E., "Inverting the Moral Economy: The Case of Land Acquisitions for Forest Plantations in Tanzania, Third World Quarterly, 36, 12 (2015), 23.

Payer, C., "Tanzania and the World Bank", Third World Quarterly, 5, 4 (1983).

Purdon, M., "Land Acquisitions in Tanzania: Strong Sustainability, Weak Sustainability and the Importance of Comparative Methods", Paper presented at the Annual World Bank Conference on Land and Poverty, Morogoro, 23 to 26 April 2012.

Schreckenberg, K. and Luttrell, C., "Participatory Forest Management: A Route to Poverty Reduction? The International Forestry Review, 11, 2 (2009).

Shelter, J. Imagining Serengeti: A History of Landscape Memory in Tanzania from the Earliest Times to the Present (Ohio University Press, Ohio, 1999).

Sunseri, T.R., Wielding the Ax: State Forestry and Social Conflict in Tanzania, 1820-2000 (Ohio University Press, Ohio, 2009).

Svendsen, K.E., "Development Strategy and Crisis Management", in Legum, C. and Mmari, G. (eds), Mwalimu, The Influence of Nyerere (James Currey, London, 1995).

United Republic of Tanzania, Ministry of Natural Resources, National Forest Programme in Tanzania, 2001-2010 (Government Printer, Dar es Salaam, 2001).

Vihemäki, H., "Politics of Participatory Forest Conservation: Cases from the East Usambara Mountains, Tanzania", The Journal of Transdisciplinary Environmental Studies, 4, 2 (2005).

Vyamana, V.G., "Participatory Forest Management in the Eastern Arc Mountains of Tanzania: Who Benefits? The International Forestry Review, 11, 2 (2009).

World Bank, Opportunities and Challenges in the Forest Sector (World Bank, Washington, 2002).

World Bank, Sao Hill Forestry Project, Phase II, Project Completion Report, Tanzania (World Bank, Washington, 1992).

World Bank, Tanzania: Sao Hill Forestry Development Project (World Bank, Washington, 1983).

Zahabu, E. et al., Forestland Tenure Systems in Tanzania: An Overview of Policy Changes in Relation to Forest Management (Norwegian University of Life Sciences, Department of Ecology and Natural Resource Management, 2009). 